\title{
COMMUNICATION METHODS ON WATER CARE DURING THE COVID-19 PANDEMIC AND ITS IMPACT ON THE RESILIENCE OF THE RURAL COMMUNITY OF “LIBERTADOR BOLÍVAR”, ECUADOR
}

\author{
GRICELDA HERRERA-FRANCO ${ }^{1,2}$, JOSELYN ALVARADO ${ }^{3,4}$, PABLO GORDILLO $^{3,4}$, \\ LENIN VEINTIMILLA ${ }^{3,4}$, BETHY MERCHAN ${ }^{2,3,4}$, PAÚL CARRIÓN-MERO $^{3,4}$ \& EDGAR BERREZUETA ${ }^{5}$ \\ ${ }^{1}$ Facultad de Ciencias de la Ingeniería, Universidad Estatal Península de Santa Elena (UPSE), Ecuador \\ ${ }^{2}$ Geo-Recursos Aplicados (GIGA), Escuela Superior Politécnica del Litoral, Ecuador \\ ${ }^{3}$ Facultad de Ingeniería en Ciencias de la Tierra, Escuela Superior Politécnica del Litoral, Ecuador \\ ${ }^{4}$ Centro de Investigaciones y Proyectos Aplicados a las Ciencias de la Tierra, \\ Escuela Superior Politécnica del Litoral, Ecuador \\ ${ }^{5}$ Departamento de Infraestructura Geocientífica y Servicios, Instituto Geológico y Minero de España, Spain
}

\begin{abstract}
The COVID-19 pandemic has had a significant impact on the life of human beings. In rural areas, water supply and wastewater management are a survival challenge. They must be supported by universities sensitive to the current reality in order to achieve the Sustainable Development Goals, in its numeral 6, water and sanitation. In rural areas across the "Santa Elena" province, due to the isolation generated, communication was affected, especially sectors such as "Libertador Bolívar", a dry-semi-arid zone located in the coastal area of Ecuador, which has access to drinking water collected from an aquifer through the service provided by the local entities. However, few know about its uses, benefits, and the maintenance that these systems require. The present study aims to validate communication methods, through the transmission of messages about the use and care of water in times of COVID-19. The methodology to follow is: i) potable and wastewater research, ii) surveys to measure knowledge about drinking water and sanitation, iii) preparation of diffusion material, iv) dissemination of messages through different digital media, and v) monitoring of social networks. It found that the Libertador Bolívar sector has a significant deficiency internet access, considering that only 8 out of 40 students at elementary school can receive virtual classes, and not necessarily through a computer, but through mobile devices; therefore, the most effective method for the information transmission were social media. Then, it proceeded to create an Instagram and Facebook page. In 4 weeks, 589 followers obtained on Facebook and 185 on Instagram, as well as significant interactions with this topic, mainly because a drought occurred (Presence of the climatic phenomenon "La Niña") that aggravated the emergency to all the inhabitants. Finally, in times of pandemic, an excellent method of communication and diffusion are the social networks, due to its easy accessibility, which reflected in the resilience of interaction in the community.
\end{abstract}

Keywords: drinking water, wastewater, COVID-19, communication, resilience, social media.

\section{INTRODUCTION}

Communication could be defined as the transmission of verbal and non-verbal messages. It consists of a sender, a receiver and channel of communication. In the process of transmitting messages, the clarity of the message may be interfered or distorted by what is often referred to as barriers [1]. According to [2], communication-education includes both intentional processes of influencing others through a structured teaching process and spontaneous learning processes. Additional factors such as the intentionality of learning and the degree of influence of the learner have to be considered. Communication processes can be classified into two categories namely mass media and group media. The Internet is included in mass media and it is focused on reaching a wide audience while the group media. According to 
[3], [4], the Internet could be considered the most popular, widespread and ubiquitous (personal) communications technology on the planet.

The use of the new techniques of information in public health is focused on improving the knowledge and transmission of relevant alerts/news [5]. However, public health problems encountered by the community are policy, economic or political related, and no amount of communication would influence change because there is a need for a policy or political decision [1].

COVID-19 is an infectious disease caused by a newly discovered coronavirus (SARSCoV-2) and is rapidly spreading around the world. According to the World Health Organization [6], COVID-19 has already affected 222 countries and territories around the world. Currently, although the vaccines for this disease are beginning their distribution, the first line of defense to fight against this pandemic is a combination of preventative measures and mitigation strategies [7]. In this way, suggestion of social distancing, environmental surface cleaning, self-isolation, travel restrictions, local and national lockdowns, quarantine, limits on large gatherings, restrictions on opening businesses, and school closures, are as some of the preventive measures that are needed to limit the spread of the disease.

In the case of Ecuador, like other countries, agglomerations are being avoided, schools and colleges are being kept closed and meetings are not allowed because of fears of contagion. In this way, the government has established that classes must be held virtually. However, in the province of Santa Elena, not all inhabitants have access to internet. According to the 2010 census, just $7.2 \%$ have access to this service, $13.5 \%$ have access to a computer and $72.1 \%$ have access to a mobile phone [8]. According to [9], the use of alternative media such as the radio or the peripheral was very popular in rural areas.

In the selected rural area (sector Libertador Bolivar), where the residents live mainly from fishing and tourism in the area, the access and distribution of water requires special care. The area is supplied with drinking water by the community water board JAAPMAN, through the extraction of groundwater [10], [11]. It provides service to 6 communities, including the parish of Libertador Bolivar [12]. The board is also in charge of transmitting information on water supply and management [13], ancestral practices have been relevant mechanisms to handle water shortage problems [14]. However, the university-community interaction has carried out different service projects to the community that range from geology and hydrogeology studies to green filter systems for Urban wastewater treatment [15].

In the case of wastewater, the stabilization ponds system has not been formally handed over to them. However, few are aware of the special care and maintenance that these systems require in sanitation terms. In addition, the area has no official communication system to overcome the existing mobility restrictions. However, the extensive use of mobile phones and applications such as WhatsApp, Instagram and Facebook, could be a suitable means of communication for less playful issues [16].

The Internet is positioning as the platform that accumulates large amounts of knowledge, which contributes to people who sometimes do not have much information or academic knowledge, producing thousands of contents that can be not only accurate, but also surprising and imaginative, and that is why we are talking about "the science of networks or network culture" [17]. Specifically, social networks are a fundamental method of communication in several areas, including education. Moreover, we are aware of its potential, because it not only generates new ways of learning, such as collaborative learning, but also promises infinite information and the opportunity for interconnectivity that could be good or bad, depending on the case [18]. Social networks have demonstrated their usefulness in education, in some studies that have been carried out [19], [20], improving productivity and encouraging people to continue learning. 
This background leads us to propose this project whose objective is to validate communication methods, through the transmission of messages about the use and care of water during the COVID-19 pandemic and its impact on the resilience of the Libertador Bolívar commune that allows the generation of awareness about the rational use of water.

\section{METHODOLOGY}

There were five phases. A general outline of the process followed is shown in Fig. 1.

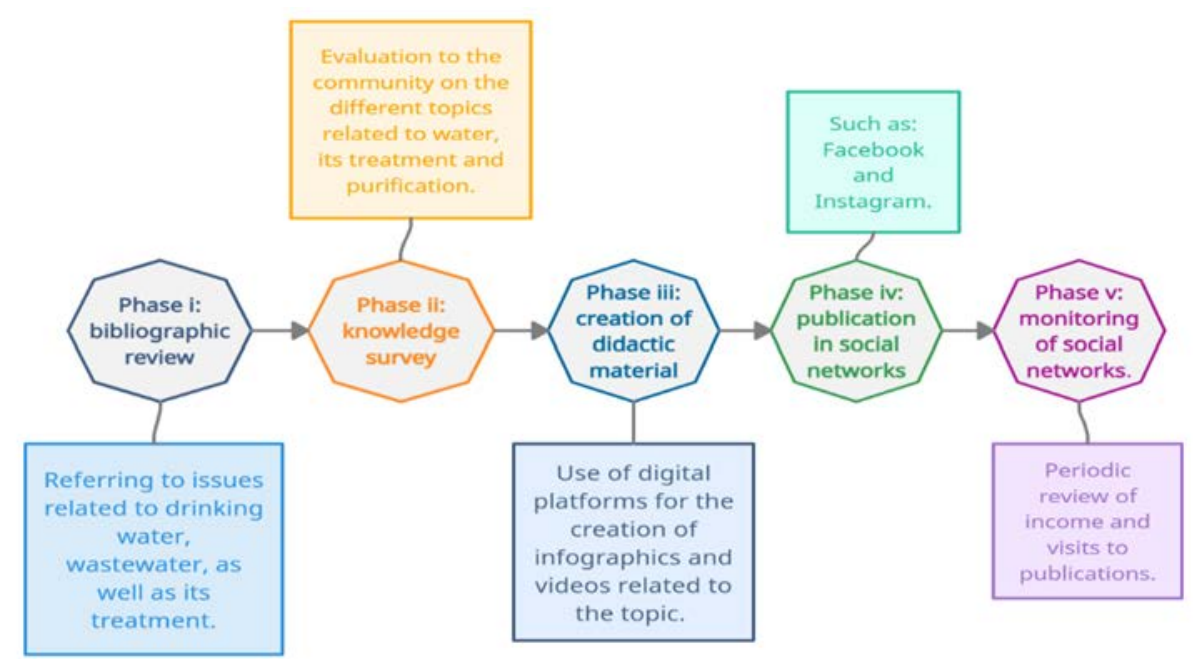

Figure 1: General diagram of the phases followed during the investigation.

Phase i. Bibliographic review. In this phase, an in-depth research was conducted on all topics related to raw water, drinking water, wastewater and its treatment, water use and importance and care of the water resource. In addition, the review of various national and international regulations that regulate the quality of the processes, of different types of wastewater treatment and, finally, information on their impact on the environment and repercussions on health was addressed.

Phase ii. Knowledge survey. Based on the information from the previous phase, two surveys of 10 and 9 questions each were formulated. One survey was for drinking water and the other one was for wastewater and wastewater treatment systems.

For the survey that was about drinking water, there were five levels of knowledge for questions from 1 to 9: level 1: "No, I'm totally unaware", level 2: "Not really, I have little knowledge", level 3: "Basic knowledge", level 4: "Yes, I have a lot of knowledge", and level 5: "Yes, I'm an expert". In question number 10, was asked "If they would like to acquire new knowledge about drinking water", giving options of answers in the selection.

For the wastewater survey, 9 questions were asked about general wastewater issues, with concrete answers, to determine how much knowledge and interest the inhabitants of the commune had about issues related to wastewater and its treatment.

The surveys were conducted online from 27 September to 20 October 2020 using the Google Forms and ArcGIS Survey platforms, which are among the most recommended applications for conducting online surveys [21], [22]. In order to contact the main authorities of the commune, as well as people from neighboring areas, it was assisted by the members 
of the Administrative Board of Manglaralto Potable Water, JAAPMAN; thus, a total of 42 people were surveyed.

Phase iii. Creation of didactic material. This phase was oriented to the design of infographics and videos. Specifically, the topics researched in the first phase and the results of the second phase were organized to create messages that are easy for the public understanding. The characteristic of the messages is that they should be short, simple, and not consume the audience's computer resources (megabytes). Once this stage is passed, the messages would be ready for publication, diffusion, and monitoring.

Phase iv. Publication and diffusion in social networks. This phase focused on the transmission of all the didactic material. At first it was transmitted through WhatsApp messages to a former official of the municipality who helped with the initial diffusion of the material, thus ensuring that the information reaches the population. In addition, a Facebook and Instagram accounts were created to upload these messages and videos, so that the information is available to all the public interested in issues of care and importance of drinking water, wastewater, and its treatment. Likewise, we sought to add people from the municipality to obtain feedback and improve the content through these platforms.

Phase v. Monitoring of social networks. This last stage focused on monitoring what was published. Specifically, it was analyzed each of the publications on the networks, how many visits there were on both Facebook and Instagram accounts, as well as how many people accessed the page, the views that these generated in each of the publications, as well as the comments that were made about the content. This information was used to determine how effective was the use of social networks as a means of diffusing information in times of pandemic.

\section{RESULTS}

Phase i. The research was divided into two general topics; the first on drinking water issues and the second on wastewater, to use this information in the following phases, create the didactic material to be published on social networks. The specific results are presented in Table 1.

Table 1: Synthesis of the bibliographic review carried out for drinking water and wastewater.

\begin{tabular}{|l|l|}
\hline Drinking water issues & Wastewater issues \\
\hline National and International Regulations & National and International Regulations \\
\hline $\begin{array}{l}\text { Procedure for obtaining drinking water } \\
\text { - } \quad \text { Surface water }\end{array}$ & $\begin{array}{l}\text { Purification systems in small } \\
\text { communities }\end{array}$ \\
\hline Raw water treatment & $\begin{array}{l}\text { History of stabilization ponds in the } \\
\text { Ecuador }\end{array}$ \\
\hline Drinking water distribution system & Wastewater, origin, and definition \\
\hline $\begin{array}{l}\text { Ways to save and take care of drinking water } \\
\text { - In home }\end{array}$ & $\begin{array}{l}\text { Types of stabilization ponds, proper } \\
\text { use, and maintenance }\end{array}$ \\
\hline Benefits of good water use and care & Optimization of stabilization ponds \\
\hline Consequences of wasting water & $\begin{array}{l}\text { Benefits of good use of stabilization } \\
\text { ponds }\end{array}$ \\
\hline Water cycle & $\begin{array}{l}\text { Consequences of misuse of } \\
\text { stabilization ponds }\end{array}$ \\
\hline
\end{tabular}


Phase ii. The application of the surveys was carried out from September 27, 2020, to October 20,2020, obtaining a total of 42 people. The results for drinking water are shown in Table 2, and for wastewater in Table 3.

Table 2: Results of the survey conducted for drinking water.

\begin{tabular}{|c|c|c|c|c|c|c|c|}
\hline \# & Question & Option & Results & $\#$ & Question & Option & Results \\
\hline \multirow{5}{*}{1} & \multirow{5}{*}{$\begin{array}{l}\text { Do you know } \\
\text { where your } \\
\text { drinking water } \\
\text { comes from? }\end{array}$} & $\begin{array}{l}\text { "No, I'm totally } \\
\text { unaware" }\end{array}$ & $8 \%$ & \multirow{5}{*}{6} & \multirow{5}{*}{$\begin{array}{l}\text { Are you aware } \\
\text { of the } \\
\text { consequences of } \\
\text { wasting drinking } \\
\text { water? }\end{array}$} & $\begin{array}{l}\text { "No, I'm totally } \\
\text { unaware" }\end{array}$ & $0 \%$ \\
\hline & & $\begin{array}{l}\text { "Not really, I have } \\
\text { little knowledge" }\end{array}$ & $25 \%$ & & & $\begin{array}{l}\text { "Not really, I have } \\
\text { little knowledge" }\end{array}$ & $33 \%$ \\
\hline & & "Basic knowledge" & $46 \%$ & & & "Basic knowledge" & $25 \%$ \\
\hline & & $\begin{array}{c}\text { "Yes, I have a lot of } \\
\text { knowledge" }\end{array}$ & $13 \%$ & & & $\begin{array}{c}\text { "Yes, I have a lot of } \\
\text { knowledge" }\end{array}$ & $17 \%$ \\
\hline & & "Yes, I'm an expert" & $8 \%$ & & & "Yes, I'm an expert" & $25 \%$ \\
\hline \multirow{5}{*}{2} & \multirow{5}{*}{$\begin{array}{l}\text { Do you know } \\
\text { the process } \\
\text { used to make } \\
\text { the water } \\
\text { drinkable? }\end{array}$} & $\begin{array}{l}\text { "No, I'm totally } \\
\text { unaware" }\end{array}$ & $21 \%$ & \multirow{5}{*}{7} & \multirow{5}{*}{$\begin{array}{c}\text { Do you know } \\
\text { where drinking } \\
\text { water goes after } \\
\text { it is used in your } \\
\text { home? }\end{array}$} & $\begin{array}{l}\text { "No, I'm totally } \\
\text { unaware" }\end{array}$ & $4 \%$ \\
\hline & & $\begin{array}{l}\text { "Not really, I have } \\
\text { little knowledge" }\end{array}$ & $25 \%$ & & & $\begin{array}{l}\text { "Not really, I have } \\
\text { little knowledge" }\end{array}$ & $21 \%$ \\
\hline & & "Basic knowledge" & $33 \%$ & & & "Basic knowledge" & $17 \%$ \\
\hline & & $\begin{array}{l}\text { "Yes, I have a lot of } \\
\text { knowledge" }\end{array}$ & $17 \%$ & & & $\begin{array}{l}\text { "Yes, I have a lot of } \\
\text { knowledge" }\end{array}$ & $33 \%$ \\
\hline & & "Yes, I'm an expert" & $4 \%$ & & & "Yes, I'm an expert" & $25 \%$ \\
\hline \multirow{5}{*}{3} & \multirow{5}{*}{$\begin{array}{l}\text { Do you know } \\
\text { how to make } \\
\text { good use of } \\
\text { drinking } \\
\text { water? }\end{array}$} & $\begin{array}{l}\text { "No, I'm totally } \\
\text { unaware" }\end{array}$ & $4 \%$ & \multirow{5}{*}{8} & \multirow{5}{*}{$\begin{array}{c}\text { Do you know } \\
\text { about measures } \\
\text { to save drinking } \\
\text { water } \\
\text { consumption? }\end{array}$} & $\begin{array}{l}\text { "No, I'm totally } \\
\text { unaware" }\end{array}$ & $4 \%$ \\
\hline & & $\begin{array}{l}\text { "Not really, I have } \\
\text { little knowledge" }\end{array}$ & $13 \%$ & & & $\begin{array}{l}\text { "Not really, I have } \\
\text { little knowledge" }\end{array}$ & $34 \%$ \\
\hline & & "Basic knowledge" & $54 \%$ & & & "Basic knowledge" & $33 \%$ \\
\hline & & $\begin{array}{c}\text { "Yes, I have a lot of } \\
\text { knowledge" }\end{array}$ & $21 \%$ & & & $\begin{array}{c}\text { "Yes, I have a lot of } \\
\text { knowledge" }\end{array}$ & $25 \%$ \\
\hline & & "Yes, I'm an expert" & $8 \%$ & & & "Yes, I'm an expert" & $4 \%$ \\
\hline \multirow{5}{*}{4} & \multirow{5}{*}{$\begin{array}{c}\text { Do you } \\
\text { understand } \\
\text { how important } \\
\text { it is to take } \\
\text { care of } \\
\text { drinking } \\
\text { water? }\end{array}$} & $\begin{array}{l}\text { "No, I'm totally } \\
\text { unaware" }\end{array}$ & $4 \%$ & \multirow{5}{*}{9} & \multirow{5}{*}{$\begin{array}{l}\text { Do you use any } \\
\text { drinking water } \\
\text { saving method? }\end{array}$} & $\begin{array}{l}\text { "No, I'm totally } \\
\text { unaware" }\end{array}$ & $25 \%$ \\
\hline & & $\begin{array}{l}\text { "Not really, I have } \\
\text { little knowledge" }\end{array}$ & $17 \%$ & & & $\begin{array}{l}\text { "Not really, I have } \\
\text { little knowledge" }\end{array}$ & $13 \%$ \\
\hline & & "Basic knowledge" & $33 \%$ & & & "Basic knowledge" & $33 \%$ \\
\hline & & $\begin{array}{l}\text { "Yes, I have a lot of } \\
\text { knowledge" }\end{array}$ & $25 \%$ & & & $\begin{array}{c}\text { "Yes, I have a lot of } \\
\text { knowledge" }\end{array}$ & $21 \%$ \\
\hline & & "Yes, I'm an expert" & $21 \%$ & & & "Yes, I'm an expert" & $8 \%$ \\
\hline \multirow{5}{*}{5} & \multirow{5}{*}{$\begin{array}{c}\text { Are you aware } \\
\text { of the benefits } \\
\text { of taking care } \\
\text { of your } \\
\text { drinking } \\
\text { water? }\end{array}$} & $\begin{array}{c}\text { "No, I'm totally } \\
\text { unaware" }\end{array}$ & $8 \%$ & \multirow{5}{*}{$\begin{array}{l}1 \\
0\end{array}$} & \multirow{5}{*}{$\begin{array}{l}\text { Would you like } \\
\text { to acquire new } \\
\text { knowledge } \\
\text { about drinking } \\
\text { water? (Multiple } \\
\text { option) }\end{array}$} & Water use and care & 11 \\
\hline & & $\begin{array}{l}\text { "Not really, I have } \\
\text { little knowledge" }\end{array}$ & $29 \%$ & & & $\begin{array}{l}\text { Measures to save } \\
\text { drinking water } \\
\text { consumption }\end{array}$ & 16 \\
\hline & & "Basic knowledge" & $17 \%$ & & & Water cycle & 6 \\
\hline & & $\begin{array}{l}\text { "Yes, I have a lot of } \\
\text { knowledge" }\end{array}$ & $29 \%$ & & & $\begin{array}{l}\text { How does water } \\
\text { reach your home? }\end{array}$ & 15 \\
\hline & & $\begin{array}{l}\text { "Yes, I'm an } \\
\text { expert" }\end{array}$ & $17 \%$ & & & $\begin{array}{l}\text { How is raw } \\
\text { water } \\
\text { transformed into } \\
\text { drinking water? }\end{array}$ & 19 \\
\hline
\end{tabular}


Table 3: Wastewater survey results.

\begin{tabular}{|c|c|c|c|}
\hline \# & Question & Option & Results \\
\hline \multirow{5}{*}{1} & \multirow{5}{*}{ What do you understand by wastewater? } & $\begin{array}{l}\text { Drinking water that has been used for } \\
\text { some human daily activity. }\end{array}$ & $17 \%$ \\
\hline & & Black water and gray water & $12 \%$ \\
\hline & & Wastewater & $29 \%$ \\
\hline & & All the above & $24 \%$ \\
\hline & & I do not know any of the above & $19 \%$ \\
\hline \multirow{2}{*}{2} & \multirow{2}{*}{$\begin{array}{l}\text { Do you know if your home/business has } \\
\text { separate wastewater pipes for rainwater and } \\
\text { greywater? }\end{array}$} & Yes & $5 \%$ \\
\hline & & No & $95 \%$ \\
\hline \multirow{3}{*}{3} & \multirow{3}{*}{$\begin{array}{l}\text { Do you believe that all wastewaters should be } \\
\text { pre-treated or discharged directly into a body } \\
\text { of water? }\end{array}$} & Yes, it should be treated beforehand & $63 \%$ \\
\hline & & No, it should be discharged directly & $14 \%$ \\
\hline & & I am not sure & $23 \%$ \\
\hline \multirow{2}{*}{4} & \multirow{2}{*}{$\begin{array}{l}\text { Would you like to know in detail the entire } \\
\text { process to which the wastewater is subjected } \\
\text { before it is discharged? }\end{array}$} & Yes & $82 \%$ \\
\hline & & No & $18 \%$ \\
\hline \multirow{2}{*}{5} & \multirow{2}{*}{$\begin{array}{l}\text { Have you ever considered the environmental } \\
\text { impact of poor wastewater treatment? }\end{array}$} & Yes & $50 \%$ \\
\hline & & No & $50 \%$ \\
\hline \multirow{3}{*}{6} & \multirow{3}{*}{$\begin{array}{l}\text { Do you believe that wastewater could be } \\
\text { reused? }\end{array}$} & Yes & $27 \%$ \\
\hline & & No & $14 \%$ \\
\hline & & Maybe & $59 \%$ \\
\hline \multirow{5}{*}{7} & \multirow{5}{*}{$\begin{array}{l}\text { If so, for which activities do you think they } \\
\text { could be used? }\end{array}$} & Drinking water & $0 \%$ \\
\hline & & Agricultural activities & $10 \%$ \\
\hline & & Irrigation & $48 \%$ \\
\hline & & None of the above & $0 \%$ \\
\hline & & Not sure & $43 \%$ \\
\hline \multirow{5}{*}{8} & \multirow{5}{*}{$\begin{array}{l}\text { Do you know some of the types of } \\
\text { wastewater treatment recommended for small } \\
\text { communities? Please list them (they could } \\
\text { answer several items): }\end{array}$} & Active sludge & 8 \\
\hline & & Sequential Discontinuous Reactors & 2 \\
\hline & & Fixed beds or trickling filters & 6 \\
\hline & & Stabilization Ponds & 14 \\
\hline & & I do not know of any & 28 \\
\hline \multirow{2}{*}{9} & \multirow{2}{*}{$\begin{array}{l}\text { Did you know that stabilization lagoons are } \\
\text { one of the best cost/benefit options for } \\
\text { wastewater treatment? (Multiple option) }\end{array}$} & Yes & $18 \%$ \\
\hline & & No & $82 \%$ \\
\hline
\end{tabular}

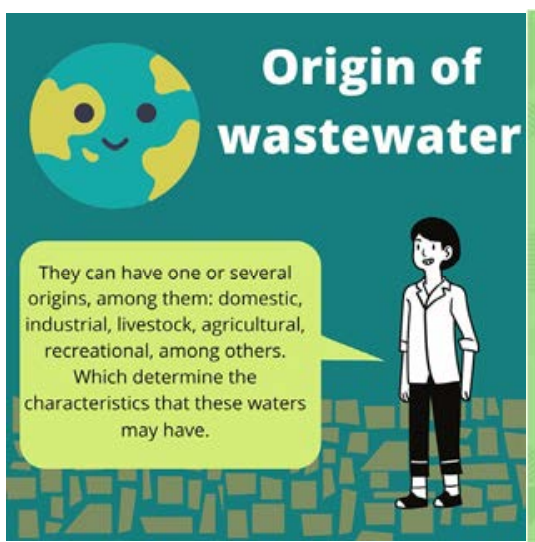

(a)

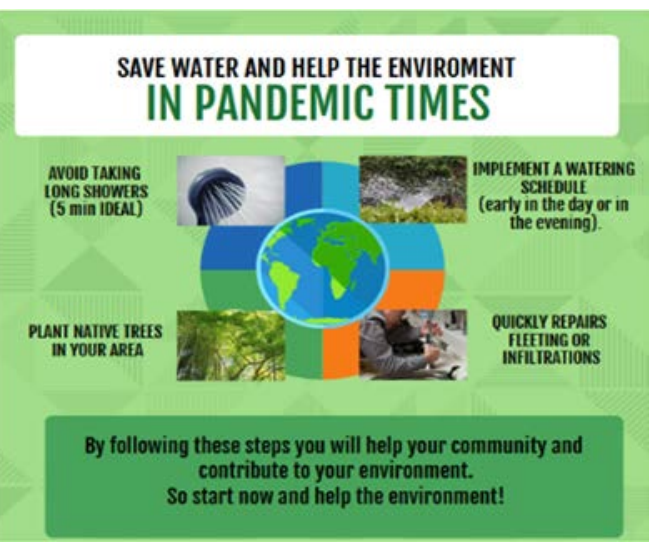

(b)

Figure 2: (a) and (b) Some examples of the infographics made. 
Phase iii: Some examples of the infographics that were created are presented in Fig. 2(a) and 2(b), in total 23 infographics were created.

Phase iv. After creating and reviewing each didactic material, it was published on each of the Facebook and Instagram pages, as well as shared with community officials via WhatsApp, so that they could share it with their acquaintances and friends in the community. The publication on social networks was diffused on both platforms because they work under the same company, so each of the publications made on the Instagram page were replicated on Facebook. Many factors were considered for the publications to reach a greater number of people, factors such as, for example, that at the time of sharing them, they have hashtags related to the topic to be addressed in the publication so that they reach not only followers, but also other people interested in the topic.

Phase v. We proceeded to monitor each of the networks to observe how much influence, the publications had on people, how they interacted, how many visits each of the publications had, as well as the comments made by the followers. Most of them were people from the Libertad Bolivar community and other areas around.

\section{ANALYSIS OF RESULTS}

Phase i. After researching the different topics, it was found that there is limited information on stabilization ponds in Ecuador; therefore, it was necessary to resort to information gathered in other Latin American countries. On the opposite, for drinking water the information is vast at the local, regional, and international levels.

Phase ii. A total of 42 people responded to the surveys. The level of knowledge regarding drinking water is within levels 1, 2 and 3, with level 3 being the highest with $34 \%$ of people. In addition, it made it possible to determine the scope of messages and what type of information was the most recommendable to transmit. The work also identified that most people $(68 \%)$ have empirical knowledge of all the topics presented, i.e., they do not have the theoretical foundations. It is important to emphasize that only $32 \%$ accepted to have a complete knowledge of all these topics on drinking water.

The results also indicate an interest in the concept of wastewater, the process that wastewater undergoes before being discharged into a water body, the types of wastewater treatment recommended in small communities, the environmental impact of poor treatment, and finally, the ways and means of reusing treated wastewater. The results also indicate a general lack of knowledge of these issues on the part of the population. For example, $63 \%$ of those surveyed believe that it is necessary for wastewater to receive treatment prior to final discharge. Along the same lines, $82 \%$ of those surveyed would be interested in having a basic knowledge of how wastewater treatment is carried out.

Phase iii. Videos and infographics were created in accordance with the topics determined by the surveys and researched in phase i. For the design, the greatest difficulty was to make the graphic and written content concise and pleasing to the eye for better understanding; this was checked by going through a review phase before publication, then the final designs were approved.

Phase iv. Among the various publications made, some infographics were posted about the types of wastewater treatment in small communities, which did not have a great "acceptance" compared to the other publications, since the quantitative variables that have been used to measure the impact of these, such as number of "likes", comments, posts to conversations and profile visits, were not even like those of previous publications. Perhaps this was since the content is not attractive enough for the user of the platform, therefore, it is advised that, in similar topics, the development of a video could be a better option since it would attract attention, since it is a very interesting topic, but also requires more verbal explanation and 
not only textual as provided by the infographic. Additionally, it also marks the lack of knowledge of the population about this type of processes, and that they do not generate greater curiosity to know them either.

Phase v. Through network monitoring it was determined that despite the impediment that not all young people have access to the internet and that very few have a smartphone, in one month a total reach of approximately 1908 people was obtained, a very relevant figure considering the size of the population to which the campaign was directed. This represents a total of 185 followers in the Instagram account. Fig. 3 shows the reach (number of people who saw the publications). As well as a total of 580 followers on the Facebook page. At this point the profiles of the followers were checked, and most of them are from neighboring areas of the commune. The results were encouraging, obtaining great social acceptance to the messages disseminated, even receiving suggestions to implement more content, the community was willing to learn more about the subject, thus proving that social networks are a very excellent means of disseminating messages in times of pandemic.

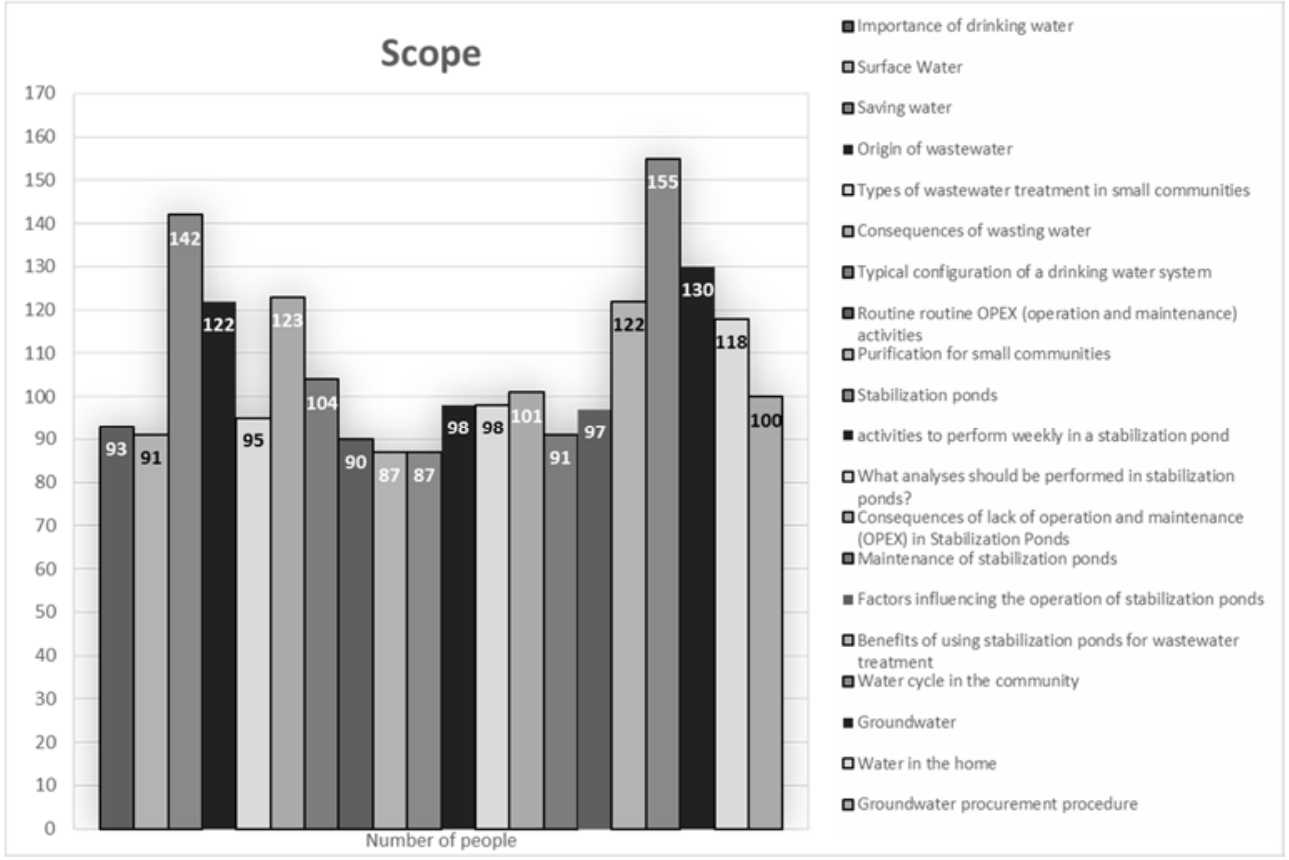

Figure 3: Number of people who watched each post on Instagram, from September 9 to October 6, 2020.

If you wish to review the content published on the pages below are shared each of the direct links to the networks created:

- https://www.facebook.com/cuidadocalidadagua

- https://www.instagram.com/cuidado_calidad_agua/

This initiative is within the framework of a project 'Unit of Linkage with Society' that works on participatory models [10], [20], to promote resilience in the face of different 
problems around water [11], while recognizing possibilities for geotourism for the sector [23].

\section{CONCLUSIONS}

From the point of view of the results obtained from the surveys on drinking water, wastewater and stabilization ponds, it is shown that the knowledge of the population is limited, but at the same time there is a great interest in knowing it.

- Due to the pandemic, communication with the inhabitants of the commune was affected and it was not possible to reach a more representative sample of the population, since only 42 people responded to the initial survey. This revealed the problem of getting messages across in times of pandemic.

- Despite all the difficulties in the study period, where there were restrictions and limitations to mobility, this community was resilient: they took the time to pay attention to the research carried out, answer the surveys, showed their concern for the vital liquid, indirectly, people became aware of the importance of water, and the best result was the interaction of people in the community reflected in social networks, which reached very significant values that were not really expected.

- The use of social networks as a channel for disseminating information is a vital tool in times of pandemic. Both Instagram and Facebook, due to their lower consumption of megabytes, were key to receiving information through their mobile phones, to which $70 \%$ of the population has access. There was a clear interest among the residents of the commune and surroundings in relation to the published topics.

However, challenges remain, such as further developing interest with new publications, to achieve a community supported with accurate and sustainable information. This project became an initial step that will be projected in various development initiatives to strengthen resilience in rural communities.

\section{REFERENCES}

[1] Munodawafa, D., Communication: Concepts, practice and challenges. Health Education Research, 23(3), pp. 369-370, 2008.

[2] del Corral, A., La intersección edu-comunicativa. Comunicar, 22, pp. 13-20, 2004.

[3] ITU-D, Telecom World Geneva, 2021. http://www.itu.int/ITU-D/ict/material/Telecom 09 flyer.pdf. 2009. Accessed on: 12 Mar. 2021.

[4] Gagnon, D.J., Mobile learning environments. Educause Quarterly, 33(2), p. 10, 2010.

[5] Gupta, D., Bhatt, S., Gupta, M., \& Tosun, A.S., Future smart connected communities to fight COVID-19 outbreak. Internet of Things, 13, p. 100342, 2021.

DOI: $10.1016 /$ j.iot.2020.100342.

[6] WHO, Weekly epidemiological update - 22 December 2020. https://www.who.int/ publications/m/item/weekly-epidemiological-update---22-december-2020. Accessed on: 12 Mar. 2021.

[7] CDC, COVID-19. https://www.cdc.gov/coronavirus/2019-ncov/index.html. Accessed on: 12 Mar. 2021.

[8] INEC, Fascículo provincial Santa Elena. 2010. https://www.ecuadorencifras.gob.ec/ wp-content/descargas/Manu-lateral/Resultados-provinciales/santa_elena.pdf.

Accessed on: 12 Mar. 2021.

[9] Moreno, Ó.J.C., Reflexiones sobre la educación rural en el marco de la comunicacióneducación. Civilizar: Ciencias Sociales y Humanas, 8(1), pp. 89-102, 2008. 
[10] Herrera-Franco, G., Alvarado-Macancela, N., Gavín-Quinchuela, T. \& Carrión-Mero, P., Participatory socio-ecological system: Manglaralto-Santa Elena, Ecuador. Geology, Ecology, and Landscapes, 2(4), pp. 303-310, 2018.

DOI: $10.1080 / 24749508.2018 .1481632$.

[11] Herrera-Franco, G., Carrión-Mero, P., Aguilar-Aguilar, M., Morante-Carballo, F., Jaya-Montalvo, M. \& Morillo-Balsera, M.C., Groundwater resilience assessment in a communal coastal aquifer system. The case of Manglaralto in Santa Elena, Ecuador. Sustainability, 12(19), p. 8290, 2020. DOI: 10.3390/su12198290.

[12] Rivera Vinces, G., Diseño de dique para embalsamiento de agua dulce en la comuna Libertador Bolívar, Provincia de Santa Elena. Escuela Superior Politécnica del Litoral (ESPOL), 2019.

[13] Valencia Robles, J.I., Análisis hidrogeológico de la cuenca del río Manglaralto para la caracterización de sus sistemas acuíferos. Escuela Superior Politécnica del Litoral (ESPOL), 2017.

[14] Carrión, P., Herrera, G., Briones, J., Sánchez, C. \& Limón, J., Practical adaptations of ancestral knowledge for groundwater artificial recharge management of Manglaralto Coastal Aquifer, Ecuador. WIT Transactions on Ecology and the Environment, pp. 375-386, 2018. DOI: 10.2495/SDP180341.

[15] Morante Carballo, F., Marcatoma Brito, L., Carrión Mero, P., Aguilar Aguilar, J.M. \& Ramírez, T., Urban wastewater treatment through a system of green filters in the Montañita commune, Santa Elena, Ecuador. WIT Transactions on Ecology and the Environment, pp. 233-249, 2019. DOI: 10.2495/WS190211.

[16] ManabiNoticias, Preocupación en sector rural ha provocado el anuncio de retornar a clases, 2020. https://manabinoticias.com/preocupacion-en-sector-rural-ha-provocadoel-anuncio-de-retornar-a-clases/. Accessed on: 12 Mar. 2021.

[17] Vivar, J.M.F., Nuevos modelos de comunicación, perfiles y tendencias en las redes sociales. Comunicar, 17(33), pp. 73-81, 2009.

[18] Buxarrais, M.R., Redes sociales y educación. Education in the Knowledge Society, 17(2), pp. 15-20, 2016 (in Spanish).

[19] Bosch, T.E., Preez, A. \& Michell, L., Using online social networking for teaching and learning: Facebook use at the University of Cape Town. South African Journal for Communication Theory and Research, 35(2), pp. 185-200, 2009.

[20] Wang, Q., Woo, H.L., Quek, C.L., Yang, Y. \& Liu, M., Using the Facebook group as a learning management system: An exploratory study. British Journal of Educational Technology, 43(3), pp. 428-438, 2012.

[21] Villalobos C., Los 20 mejores programas para crear encuestas online. https://blog.hubspot.es/service/crear-encuestas-online. (In Spanish.)

[22] Law D., 5 Reasons to Use Survey123 for ArcGIS. https://www.esri.com/about/ newsroom/arcuser/5-reasons-to-use-survey123-for-arcgis/.

[23] Gricelda, H.F., Paúl, C.M. \& Niurka, A.M., Participatory process for local development: Sustainability of water resources in rural communities: Case Manglaralto-Santa Elena, Ecuador. Handbook of Sustainability Science and Research. World Sustainability Series, ed. L.F.W., Springer: Cham, pp. 663-676, 2018.

[24] Herrera-Franco G. et al., Geosites and georesources to foster geotourism in communities: Case study of the Santa Elena Peninsula Geopark Project in Ecuador. Sustainability, 12(11), p. 4484, 2020. DOI: 10.3390/su12114484. 